\title{
KAJIAN PANOPTISISME DAN ARSITEKTUR KONTROL DALAM PERATURAN PEMBANGUNAN GEREJA KATOLIK
}

\author{
Sherly de Yong \\ Program Studi Desain Interior, Fakultas Seni dan Desain, Universitas Kristen Petra, \\ Jl. Siwalankerto 121 - 131, Surabaya \\ Email: sherly_de_yong@petra.ac.id
}

\begin{abstract}
Abstrak
Michel Foucault mengenalkan sebuah mekanisme kekuasaan untuk meningkatkan pengawasan melalui penataan arsitektur yang disebut sebagai panoptisisme. Keterkaitan antara arsitektur kontrol dan panoptisisme terhadap peraturan pembangunan gereja Katolik merupakan inti permasalahan dari penelitian ini. Tujuan penelitian ini adalah untuk mengkaji keterkaitan prinsip panoptisisme arsitektur ini dengan teori arsitektur khususnya teori arsitektur kontrol sehingga menghasilkan sebuah tolok ukur yang kemudian digunakan untuk melihat keterkaitan prinsip panoptisisme ini pada peraturan pembangunan gereja Katolik. Metode yang digunakan adalah metode kritik deskriptif dan interpretif, hasil yang didapatkan bahwa panoptikon yang merupakan landasan panoptisisme (baik pengawasan panoptisisme yang mengawasi dan yang diawasi), juga merupakan bagian dari arsitektur khususnya arsitektur kontrol. Dari teori panoptisisme ditemukan keenam elemen panoptisisme (penyekatan, pengelompokan, kontrol aktivitas, orientasi, hirarki dan sistem pengawasan) dimana elemen panoptisisme yang paling berpengaruh di dalam arsitektur adalah elemen prinsip penyekatan. Kemudian dengan menggunakan metode analisis kritik normatif dan interpretif untuk melihat keterkaitan konsep ini di dalam gereja, hasil yang didapatkan bahwa gereja Katolik memiliki sistem pengontrolan dan pengaturan disiplin panoptisisme (pengawasan panoptisisme dari sudut pandang yang diawasi) terhadap umatnya, salah satunya dengan adanya PUMR/Pedoman Umum Misale Romawi, dimana di dalam pedoman ini dituliskan mengenai aturan-aturan baku yang ada di dalam gereja Katolik.
\end{abstract}

Kata kunci: panoptisisme, ruang, arsitektur kontrol, gereja Katolik.

\begin{abstract}
Title: Exploration of Panopticism and Architecture of Control in Building Guidance for Catholic Church

Michel Foucault introduces a mechanism to increase surveillance powers through architectural arrangement, referred to as panopticism. The connection between control of architecture and panopticismin the Catholic church is the main problem of this research. The purpose of this study is to determine the panopticism in architectural field, examine the relationship between principles of panopticism with architectural theory, especially the theory of the architecture of control, to produce a benchmark that can be used to analize the regulation in Catholic church. Through descriptive analysis and critique interpretive method, the results obtained are that panopticon and panopticism are also part of the architecture of control. From the theory of panopticon, there are six elements of panopticism can be derived (segmenting, grouping, control activities, orientation, hierarchy and control system); the most influential element in the architecture is the element of Control System. To analyze the church, we are using normative and interpretive criticism methods. The results is that the Catholic church has a system of controlling and regulating the discipline panopticism (especially panopticism supervision from the supervised vision) using the general guidance of Roman Missale as the catholic standard rules.
\end{abstract}

Keywords: panopticism, space, control of architecture, Catholic church. 


\section{Pendahuluan}

Michel Foucault yang dikenal sebagai tokoh pasca - strukturalisme memperkenalkan mengenai panopticon dan disciplinary power yang dituliskan di dalam bukunya Discipline and Punishment (1977). Di dalam buku ini, Foucault menuliskan sebuah teknik dan mekanisme untuk mengoptimalkan penerapan disciplinary power melalui peningkatkan pengawasan dan pendisiplinan kekuasaan pada penataan ruang, dan aktivitas. Prinsip ini yang kemudian disebut dengan panoptisisme atau dalam bahasa Inggrisnya disebut Panopticism. Kata panoptisisme ini terinspirasi dari rancangan panoptikon oleh Jeremy Bentham. Foucault mengungkapkan bahwa panoptikon merupakan contoh ruang yang memiliki bentuk karakter kekuasaan/ kekuatan. Panoptikon diungkapkan oleh Foucault bukanlah sebagai penjara, namun merupakan model yang merangkum karakteristik masyarakat yang berdasar pada disciplinary power. (Leach, 1997).

Ruang kuasa panoptisisme ini bisa dikatakan sebagai ruang yang terbentuk karena adanya mekanisme disciplinary power, melalui penataan ruang, aktivitas manusia dan pengawasan. Panoptisisme merupakan bagian dan mekanisme pelaksanaan dari disciplinary power. Dengan adanya mekanisme panoptisisme (melalui penataan ruang, aktivitas dan pengawasan) ini, diharapkan manusia yang berada di dalamnya berperilaku disiplin sesuai kuasa yang diinginkan dari pemilik kuasa.

Di dalam arsitektur sendiri, terdapat bermacam-macam teori. Mulai dari teori perilaku arsitektur sampai dengan teori arsitektur kontrol. Arsitektur kontrol diperlukan untuk mengarahkan dan atau mencegah tipe perilaku tertentu di dalam ruang yang disediakan. Ide dari arsitektur kontrol adalah membentuk perilaku pengguna melalui lingkungan buatan. Ketika kita berdiskusi mengenai arsitektur kontrol, ada dua elemen yang perlu diperhatikan, yaitu desain arsitektur yang mengontrol secara fisik untuk mengarahkan tipe perilaku tertentu dan desain arsitektur yang mengatur perilaku pengguna melalui dampak psikologi dari lingkungan buatan/ bangunan sekitar. Sebagai contoh, teori arsitektur kontrol tindakan kejahatan adalah sebuah teori mengenai bagaimana mengurangi tindakan kejahatan melalui pengelolaan arsitektur.

Teori arsitektur kontrol ini memiliki makna yang sesuai dengan apa yang diungkapkan oleh Foucault melalui tulisan disciplinary power dan panoptisismenya. Di dalam teori arsitektur kontrol ini, dituliskan mengenai bagaimana memaksimalkan bangunan desain arsitektur untuk membantu di dalam mengontrol tindakan kejahatan di sebuah bangunan melalui mekanisme dan konsep (Katyal, 2002). Panoptisisme mengontrol manusia melalui mekanisme dari sebuah arsitektur. Teori arsitektur kontrol ini memiliki empat konsep pendukung (Katyal, 2002) yaitu: pengawasan secara natural, teritori, pengisolasian sosial, melindungi target sasaran yang sesuai.

Bangunan gereja Katolik merupakan salah satu bangunan-ruang yang digunakan untuk mewadahi kebutuhan spiritual dan aktivitas beribadah manusia yang beragama Katolik. Bangunan ruang gereja Katolik juga berfungsi sebagai prasarana upacara keagamaan atau religi dan merefleksikan ibadah Katolik. 
Bangunan ruang gereja Katolik memiliki sejarah yang lama di dalam peradaban manusia. Bangunan ruang gereja Katolik memiliki pola ruang tertentu yang berbeda dengan bangunan lain. Misalnya bentuk atap tinggi menjulang memaknai adanya hubungan vertikal antara Tuhan dan manusia.

Gereja Katolik, di dalam perkembangannya, memiliki sistem pengontrolan dan pengaturan disiplin terhadap umatnya. Hal ini terlihat dengan adanya aturan-aturan baku (seperti tata cara liturgi gereja Katolik) yang ditetapkan oleh Vatikan (yang merupakan tempat pimpinan tertinggi Katolik/Paus berada) dan adanya peraturan pembangunan gereja Katolik yang tertulis di dalam peraturan The General Instruction of the Roman Missal (www.romanmissal.org.uk) atau di dalam bahasa Indonesianya PUMR (Pedoman Umum Misale Romawi/PUMR, 1969). Contoh lainnya, gereja Katolik mengeluarkan dekrit tentang inkulturasi di dalam gereja yang ditetapkan oleh Paus. Dekrit tentang inkulturasi ini digunakan sebagai salah satu cara gereja Katolik membuka dirinya kepada masyarakat dengan tidak meninggalkan tradisi Katolik namun mengontrol dan mengatur pendisiplinan terhadap umatnya. Pendisiplinan di sini memiliki makna yang sama seperti yang diungkapkan oleh Foucault, yaitu pendisiplinan untuk menerapkan kekuasaan atau panoptisisme.

Penelitian ini, akan mengembangkan teori panoptisisme dan teori arsitektur kontrol pada studi kasus bangunan ruang gereja Katolik. Panoptisisme disini menjadi dasar untuk meninjau adanya penerapan teori arsitektur kontrol pada bangunan ruang gereja Katolik.

\section{Metode Penelitian}

Ada dua metode penelitian yang digunakan di dalam penelitian ini yaitu analisis deskriptif dan interpretif. Pada tahapan analisis deskriptif dan interpretif terhadap data literatur, data literatur yang sudah dikumpulkan ini digunakan sebagai referensi. Analisis literatur dilakukan untuk menarik kesimpulan dari berbagai sumber pustaka tentang filsafat panoptisisme dan teori arsitektur perilaku. Perumusan ini diperlukan untuk mendapatkan sebuah parameter yang berdasarkan pada acuan literatur dan mendapatkan dasar tolok ukur penerapan panoptisisme dari sisi teori arsitektur utamanya arsitektur perilaku pada bangunan ruang gereja Katolik. Metode analisis yang digunakan adalah metode kritik deskriptif (gambaran lengkap dan deskripsi mengenai hubungan antara fenomena yang sedang diuji) dan dengan pendekatan kritik interpretif (menginterpretasikan makna-makna teks) (Groat, 2002). Setelah itu, akan dijelaskan mengenai pandangan kritis penulis mengenai bagaimana keterkaitan panoptisisme dengan arsitektur. Metode yang digunakan untuk menjelaskan ini adalah metode interpretasi dan pandangan kritis dari penulis.

\section{Hasil dan Pembahasan}

\section{Arsitektur Kontrol dan Teori Panoptisisme}

Pembahasan mengenai panoptisisme dan kaitannya dengan arsitektur khususnya ruang, selalu terkait dengan aktifitas dan perilaku dan bagaimana cara mengontrolnya. Pembahasan mengenai kaitan panoptisisme dengan ruang dilakukan dalam teori arsitektur kontrol perilaku. Lockton (2006) dalam Architecture of control in the built 
environment yang diakses pada 8 Oktober 2011 dari http://architectures.danlockton.co.uk/ar chitecture-of-control-in-the-builtenvironment/, mengungkapkan sebuah teori mengenai arsitektur kontrol atau istilahnya disciplinary architecture.

Arsitektur kontrol adalah fitur, struktur atau metode perancangan produk fisik, software, bangunan, tata kota atau perencanaan sistem untuk interaksi dengan pengguna, yang bertujuan untuk memaksakan atau membatasi perilaku pengguna. Arsitektur kontrol diperlukan jika ingin mengarahkan dan atau melarang jenis perilaku tertentu di dalam ruang yang diberikan. Ide untuk membentuk pengguna ini sudah terlihat nyata di dalam lingkungan binaan dan arsitektur mengatur perilaku (Lockton, 2006) dalam Architecture of control in the built environment yang diakses pada 8 Oktober 2011 dari http://architectures.danlockton.co.uk/ar chitecture-of-control-in-the-builtenvironment/.

Ketika kita membicarakan tentang arsitektur kontrol, ada dua hal yang perlu diperhatikan. Yang pertama adalah desain arsitektur yang mengontrol secara fisik mengarahkan tipe perilaku tertentu (arsitek dan desainer memanfaatkan struktur fisik untuk mengarahkan atau melarang perilaku/kegiatan tertentu pada ruang yang ada, misalnya seperti penggunaan pagar untuk mencegah seseorang mengakses daerah terlarang) dan yang kedua adalah desain arsitektur yang mengatur perilaku pengguna melalui dampak psikologi dari lingkungan buatan / bangunan sekitar (arsitek dan desainer memanfaatkan efek psikologis seseorang untuk membentuk perilaku, misalnya menggunakan warna-warna tertentu untuk mempengaruhi suasana hati pengguna).
Pada desain bangunan untuk arsitektur kontrol, biasanya pola desain yang digunakan melibatkan penataan fisik dari elemen bangunan (seperti penentuan posisi, pemisahan, persembunyian, dan sebagainya) dan sebuah perubahan pada properti material (tekstur, warna dan material) untuk merubah persepsi dan perilaku pengguna. Selain kedua pola ini, ada juga pola pengawasan melalui perancangan layout dan teknologi untuk menfasilitasi atau membatasi aktivitas atau jarak pandang sekelompok orang (Lockton, 2011) dalam Design with intent yang diakses pada 1 Juni 2014 dari http://architectures.danlockton.co.uk/ar chitecture-of-control-in-the-builtenvironment/.

Penggunaan metode arsitektur kontrol ini cukup banyak dipraktekkan di dalam arsitektur, misalnya seperti desain bangku-bangku taman dengan lengan di tengah-tengah bangku untuk mencegah orang tidur pada bangku taman atau penggunaan jendela pada tempat tinggi di kelas Inggris untuk memaksimalkan pencahayaan yang masuk ke dalam ruang dan mencegah para murid untuk terganggu dengan peristiwa di luar jendela. (Lockton, 2006) dalam Architecture of control in the built environment yang diakses pada 8 Oktober 2011 dari http://architectures.danlockton.co.uk/ar chitecture-of-control-in-the-builtenvironment/.

Bangunan panoptikon yang dibangun oleh Jeremy Bentham adalah salah satu contoh aplikasi desain dari arsitektur kontrol. Panoptikon bukanlah sebuah penjara melainkan sebuah prinsip umum kontruksi, pengawasan dan mesin optik untuk sekelompok manusia. Ide dari penjara panoptikon ini adalah untuk mendapatkan kontrol 
atas apa yang kelihatan (fisik narapidana) dan tidak kelihatan (psikologi dari narapidana). Secara struktur, bangunan ini berbentuk melingkar dengan sebuah menara pengawas di tengah-tengah lingkaran. Panoptisisme yang berasal dari panoptikon memiliki makna bahwa orang merasa dirinya selalu diawasi meskipun tidak bisa melihat siapa yang mengawasinya, sebaliknya yang mengawasi tidak bisa dilihat oleh orang yang diawasi. Panoptisisme merupakan contoh nyata dari arsitektur kontrol. Panoptikon merupakan sebuah contoh bangunan desain dengan karakteristik dari masyarakat yang berdasarkan pada disiplin (Foucault, 1977).

Dari literatur tentang prinsip panoptisisme, dapat disimpulkan bahwa panoptisismeadalah mekanisme dan pengembangan dari teknik dan prinsip disciplinary power (dimana disciplinary power ini merupakan sebuah model kontrol modern yang efektif).Foucault mengkonsepkan panoptisisme dari bangunan panoptikon-nya Bentham sebagai mekanisme fungsi disiplin di sebuah penjara dan mengilustrasikan fungsi disiplin sebagai alat kuasa dengan kuasa pada pihak yang mengawasi bukan di pihak yang sedang diawasi.

Foucault mendeskripsikan bahwa disiciplinary modern memiliki tiga teknik kontrol utama, yaitu observasi hirarki, penghakiman dan pengujian (Fontana-Giusti, 2013). Mekanisme dari disiplin ini, yang merupakan penggabungan antara arsitektur dan doktrin lainnya, secara teknik bisa dijelaskan di dalam lima teknik yaitu:

(1) pengembangan berpagar/enclosure,

(2) menyekat/partitioning, mengorganisasi fungsi dari bangunan termasuk jadwal dan aktivitas manusia, (4) hirarki sebagai bagian dari teknik sirkulasi disiplin unit dan penataan, dan (5) komposisi dari berbagai macam teknik termasuk teknik pengawasan (Fontana-Giusti, 2013).

Panoptisime yang diadopsi dari kata panoptikon merupakan diagram dari kuasa modern, sebuah model arsitektural yang ideal untuk menunjukkan disiplin kuasa modern. Panoptikon disini tidak diartikan sebagai sebuah bangunan melainkan sebuah mekanisme disiplin kuasa yang disederhanakan ke bentuk esensinya yaitu sebuah diagram dari teknologi politik. Panoptisisme memiliki konsep "one is totally seen without ever seeing and one sees everything without ever being seen" yang artinya ada orang yang selalu diawasi terus menerus tanpa pernah tahu siapa yang mengawasi dan di pihak lain ada orang yang selalu bisa mengawasi tanpa dilihat oleh yang diawasi. Panoptisisme yang merupakan adopsi dari bentuk bangunan panoptikon, sebuah bangunan penjara dengan menara di tengah yang memungkinkan orang yang berada di dalam menara ini melihat semua sel penjara dan narapida di dalamnya tidak bisa melihat orang yang berada di dalam menara.

Di dalam desain penjara oleh Bentham ini, tiap individu di dalam sel bisa melihat menara pengawas, namun tidak mengetahui siapa yang berada di menara pengawas. Pengawas dapat secara terus-menerus memantau individu yang berada di dalam sel tanpa pernah dapat dilihat oleh mereka yang diawasi. Mereka menjadi obyek informasi dan tidak pernah menjadi subyek komunikasi. Penguasaan terhadap individu melalui mekanisme pemantauan dan arsitektur yang dibentuk sedemikian rupa inilah yang membentuk konsep panoptisisme. Sistem panoptikon menjadi bentuk 
pengawasan yang memungkinkan untuk mendapat kepatuhan dan keteraturan dengan meminimalkan tindakan yang sulit diramalkan. Pengawasan bisa dilakukan secara diskontinyu, namun efek kesadaran diawasi kontinyu. Sistem kuasa panoptikon inilah yang membentuk kuasa menjadi lebih ekonomis dan efektif dalam hal peningkatan moral publik, penyebaran edukasi dan pengembangan ekonomi. Selain dari diagram pada bangunan penjara panoptikon secara fisik, sistem panoptikon ini juga diimbangi dengan adanya kontrol dan observasi. Dengan observasi dan klasifikasi, dapat tercipta sistem mekanisme disiplin kuasa yang lebih efisien. Mekanismepengawasan di dalam panoptisisme bisa dilihat dari dua arah, yaitu dari yang mengawasi dan yang diawasi.Panoptikon merupakan contoh dari arsitektur kontrol yang sempurna (baik kontrol secara fisik maupun psikologis).

Berdasarkan penjelasan mengenai teknik dari mekanisme disiplin kuasa dan konsep panoptisisme, maka dapat disimpulkan bahwa ada beberapa teknik yang dikembangkan dari disiplinary power dan panoptisisme, yaitu: (1) adanya sekat/partitioning dan dikelompokkan/grouping and enclosure (peripheric ring), (2) adanya kontrol dan organisasi terhadap fungsi, perilaku dan aktivitas manusia yang bisa dilakukan dengan teknik penjadwalan distribusi, pencahayaan (dimana area yang diawasi selalu lebih terang dibandingkan dengan area yang mengawasi, tujuannya adalah agar orang yang diawasi tidak bisa mengetahui gerak-gerik dari orang yang mengawasi), (3) adanya pusat orientasi dan hirarki yang menunjukkan pada ranking, dan yang terakhir (4) adanya teknik sistem yang harus dijalankan (syarat yang perlu dipatuhi oleh orang yang diawasi, supaya sistem baik itu sistem penataan interior dan sistem pengawasan/ surveillance).

Panoptisisme sangat erat hubungannya dengan perancangan sebuah bangunanruang arsitektur khususnya arsitektur kontrol dimana arsitektur berkuasa untuk kontrol mengarahkan dan atau mencegah tipe perilaku tertentu di dalam ruang yang disediakan melalui desain ruang tersebut (Lockton, 2006) dalam Architecture of control in the built environment yang diakses pada 8 Oktober 2011 dari http://architectures.danlockton.co.uk/ar chitecture-of-control-in-the-builtenvironment/. Teknik-teknik disiplin kuasa panoptisisme di atas merupakan penjabaran yang jelas bagaimana arsitektur berperan sebagai dasar dari teknik pelaksanaan disiplin kuasa panoptisisme.

Panoptisisme merupakan bagian dari arsitektur utamanya arsitektur kontrol. Arsitektur membantu kita memahami logika dari struktur dan dampak dari ruang sebagai pengendali disiplin kuasa panoptisisme dan keterkaitan prinsipprinsip panoptisisme di dalam arsitektur kontrol dengan tiga pola desain bangunan, yaitu pola penataan elemen bangunan, pola material dan pola pengawasan (Lockton, 2011) dalam Design with intent yang diakses pada 1 Juni 2014 dari http://architectures.danlockton.co.uk/ar chitecture-of-control-in-the-builtenvironment/. Berikut adalah tabel pembahasan ketiga pola desain untuk arsitektur kontrol yang lebih detail (Tabel 1). 
Tabel 1. Tabel Analisis Tolok Ukur dari Teknik Panoptisisme dan Pola Rancang Arsitektur Kontrol.

\begin{tabular}{|c|c|c|c|c|}
\hline No & $\begin{array}{l}\text { Teori } \\
\text { Panoptisisme }\end{array}$ & $\begin{array}{l}\text { Teori } \\
\text { Arsitektur } \\
\text { Kontrol }\end{array}$ & & Keterangan \& Kesimpulan \\
\hline \multirow{3}{*}{1} & \multirow{3}{*}{$\begin{array}{l}\text { Penyekat } \\
\text { (penyekatan yang } \\
\text { jelas dan } \\
\text { pengelolaan bukaan } \\
\text { yang jelas) }\end{array}$} & $\begin{array}{l}\text { Pola penataan } \\
\text { fisik elemen } \\
\text { bangunan }\end{array}$ & $\mathrm{v}$ & $\begin{array}{l}\text { Bentuk, ukuran ruang dan perabot yang } \\
\text { dimanfaatkan sebagai penyekat }\end{array}$ \\
\hline & & Pola material & $\mathrm{v}$ & $\begin{array}{l}\text { Penyekatan melalui material dan warna } \\
\text { dimana ruang berkuasa dan mengontrol } \\
\text { perilaku dan pengguna termasuk mengontrol } \\
\text { visual / pandangan pengguna. }\end{array}$ \\
\hline & & Pola pengawasan & $\mathrm{v}$ & $\begin{array}{l}\text { Sekat sebagai bagian dari perancangan } \\
\text { layout berdasarkan klasifikasi tipe ruang dan } \\
\text { teknologi }\end{array}$ \\
\hline \multirow{3}{*}{2} & \multirow{3}{*}{$\begin{array}{l}\text { Pengelompokan } \\
\text { (pengontrolan dan } \\
\text { pengawasan } \\
\text { melalui } \\
\text { pengelompokan } \\
\text { karakterisasi dan } \\
\text { klasifikasi) }\end{array}$} & $\begin{array}{l}\text { Pola penataan } \\
\text { fisik elemen } \\
\text { bangunan }\end{array}$ & $\mathrm{v}$ & $\begin{array}{l}\text { Bentuk, ukuran, perabot dan organisasi- } \\
\text { organisasi ruang yang dikelompokkan } \\
\text { (clustered) berdasarkan kedekatan fisik. }\end{array}$ \\
\hline & & Pola material & $\mathrm{v}$ & $\begin{array}{l}\text { Pengelompokan berdasarkan karakteristik } \\
\text { material dan warna }\end{array}$ \\
\hline & & Pola pengawasan & $\mathrm{v}$ & $\begin{array}{l}\text { Pengelompokan perancangan layout } \\
\text { berdasarkan tipe klasifikasi ruang dan } \\
\text { teknologi }\end{array}$ \\
\hline \multirow{3}{*}{3} & \multirow{3}{*}{$\begin{array}{l}\text { Kontrol Aktivitas } \\
\text { (pengontrolan } \\
\text { aktivitas di dalam } \\
\text { panoptisisme, } \\
\text { variabel kultur, } \\
\text { religi dan perilaku) }\end{array}$} & $\begin{array}{l}\text { Pola penataan } \\
\text { fisik elemen } \\
\text { bangunan }\end{array}$ & $\mathrm{v}$ & $\begin{array}{l}\text { Pengontrolan aktivitas dapat dilihat dari } \\
\text { aspek positioning aktivitas di dalam layout. } \\
\text { Aktivitas pengguna dikontrol melalui } \\
\text { peletakan elemen bangunan ruang }\end{array}$ \\
\hline & & Pola material & $\mathrm{v}$ & $\begin{array}{l}\text { Aktivitas pengguna bisa dibatasi melalui } \\
\text { penggunaan material yang sesuai dengan } \\
\text { aktivitas pengguna pada ruang dan perabot }\end{array}$ \\
\hline & & Pola pengawasan & $\mathrm{v}$ & $\begin{array}{l}\text { Perancangan layout sesuai klasifikasi ruang } \\
\text { akan memudahkan pengawasan dan } \\
\text { pengontrolan pengguna di dalam } \\
\text { panoptisisme }\end{array}$ \\
\hline \multirow{3}{*}{4} & \multirow{3}{*}{$\begin{array}{l}\text { Berorientasi } \\
\text { memusat (orientasi } \\
\text { pada pusat - } \\
\text { orientasi yang } \\
\text { diawasi hanya pada } \\
\text { satu titik) }\end{array}$} & $\begin{array}{l}\text { Pola penataan } \\
\text { fisik elemen } \\
\text { bangunan }\end{array}$ & $\mathrm{v}$ & $\begin{array}{l}\text { Bentuk ruang yang berorientasi dan perabot- } \\
\text { perabot yang ditata sesuai arah orientasi } \\
\text { pusat }\end{array}$ \\
\hline & & Pola material & $\mathrm{v}$ & $\begin{array}{l}\text { Warna dan material yang kontras akan } \\
\text { membantu pengguna memusatkan orientasi } \\
\text { mereka di dalam ruang }\end{array}$ \\
\hline & & Pola pengawasan & $\mathrm{v}$ & $\begin{array}{l}\text { Pencapaiannya melalui klasifikasi ruang } \\
\text { yang diorientasikan memusat dan } \\
\text { penggunaan teknologi }\end{array}$ \\
\hline \multirow{3}{*}{5} & \multirow{3}{*}{$\begin{array}{l}\text { Hirarki (hirarki } \\
\text { memiliki peranan } \\
\text { untuk mengawasi } \\
\text { bawahannya supaya } \\
\text { mereka lebih } \\
\text { terkontrol) }\end{array}$} & $\begin{array}{l}\text { Pola penataan } \\
\text { fisik elemen } \\
\text { bangunan }\end{array}$ & $\mathrm{v}$ & $\begin{array}{l}\text { Bentuk ruang, ukuran ruang dan perabot } \\
\text { yang berbeda bisa mempertegas terciptanya } \\
\text { hirarki panoptisisme }\end{array}$ \\
\hline & & Pola material & $\mathrm{V}$ & $\begin{array}{l}\text { Warna dan material yang kontras akan } \\
\text { membantu hirarki pengawasan panoptisisme }\end{array}$ \\
\hline & & Pola pengawasan & $\mathrm{V}$ & $\begin{array}{l}\text { Hirarki melalui klasifikasi ruang pada layout } \\
\text { dan juga teknologi }\end{array}$ \\
\hline 6 & $\begin{array}{l}\text { Sistem Pengawasan } \\
\text { Interior (sistem } \\
\text { pengawasan }\end{array}$ & $\begin{array}{l}\text { Pola penataan } \\
\text { fisik elemen } \\
\text { bangunan }\end{array}$ & & \\
\hline
\end{tabular}




\begin{tabular}{llll}
\hline No & $\begin{array}{l}\text { Teori } \\
\text { Panoptisisme }\end{array}$ & $\begin{array}{l}\text { Teori } \\
\text { Arsitektur } \\
\text { Kontrol }\end{array}$ & Keterangan \& Kesimpulan \\
\hline \multirow{2}{*}{$\begin{array}{l}\text { interior dengan } \\
\text { teknologi terkini.) }\end{array}$} & Pola material & - & \\
\cline { 2 - 4 } & Pola pengawasan & v & $\begin{array}{l}\text { Teknologi kamera, teknologi pada bukaan } \\
\text { (jendela dan pintu), dan peletakannya yang } \\
\text { strategis akan memudahkan pengawasan }\end{array}$ \\
\hline Keterangan v : Ada penerapannya & &
\end{tabular}

Sumber: Hasil analisis, 2016

\section{Peraturan Pembangunan Gereja Katolik}

Pada arsitektur gereja Katolik, terdapat sebuah peraturan yang digunakan di dalam perancangan dan pembangunan setiap gereja Katolik di seluruh dunia. Menurut Neufert (1997), gereja adalah bangunan yang sakral, yang memiliki makna simbolik yang mendalam pada bentukan denah (cruciform), arah (directori), proporsi (sacred geometry) dan fungsi-fungsi liturginya. Pola arsitektur gereja Barat masa lalu memiliki ciri-ciri umum sebagai berikut: bahwa dinding merupakan elemen pembatas antara daerah sakral dan profan. Selain itu area panti imam termasuk tabernakel dan salib utama di gereja merupakan suatu unsur yang penting serta menjadi pusat orientasi ruang dalam, terlihat secara langsung dan menjadi satu bagian dengan ruang umat. Berikut adalah peraturan pembangunan Gereja Katolik (Pedoman Umum Misale Romawi/PUMR, 1969), (Windhu, 1997), yang dituliskan disini sesuai dengan batasan pembahasan penelitian yang difokuskan pada ruang dalam gereja Katolik yang digunakan untuk aktivitas beribadah, meliputi area tabernakel, panti imam, area panti umat dan area transisi:

\section{Ruang Gereja}

Ruang gereja merupakan tempat umat paroki datang berhimpun untuk mendengarkan Sabda Tuhan, berdoa dan menyanyi, serta merayakan kurban Ekaristi.

2. Ruang Dalam Gereja

Ruangan dalam gereja haruslah diusahakan untuk mengungkapkan dan mendukung secara menyeluruh kesatuan umat beriman, sebab merekalah subyek yang merayakan liturgi. Situasi ruangan utama merupakan pusat kegiatan liturgi dan pusat perhatian. Tata ruang dalam gereja harus menunjukkan susunan hirarkis umat dan keanekaragaman tugas-tugas.

3. Jarak Tempat Duduk

Jarak tempat duduk, ruas jalan untuk komuni, ukuran dan bentuk tempat duduk, jarak umat dari imam antara satu sama lain harus diperhitungkan untuk kelancaran upacara liturgi dan kenyamanan umat ketika mengikuti misa.

4. Altar

Altar adalah meja besar untuk mengadakan perayaan Ekaristi dan kegiatan liturgi yang lain dan pusat utama bagi umat beriman dan merupakan poros komunitas yang melaksanakan perayaan, hendaknya jelas terlihat dari segala pihak.

5. Mimbar

Mimbar adalah tempat khusus untuk pewartaan Sabda Tuhan.

6. Tempat Duduk Pemimpin

Tempat duduk pemimpin seharusnya terlihat dengan baik oleh seluruh umat, harus menandakan sebagai tempat seorang pemimpin, dan bisa berkomunikasi langsung 
dengan umat, meskipun tempatnya berada di panti imam.

7. Tabernakel

Tabernakel adalah semacam lemari kecil untuk menyimpan hosti/ roti tak beragi.Sakramen Mahakudus / hosti berada pada tempat tabernakel yang terpisah dari panti umat. Tabernakel seharusnya diletakkan di tempat yang khusus, tidak dapat dipindahkan, kuat, tertutup dan tidak dapat dilintasi umat, mudah terlihat dari siapapun yang memasuki gereja dan disertai dengan lampu khusus yang selalu menyala sebagai tanda kehadiran Kristus.

\section{Panti Umat}

Tempat duduk umat seharusnya mendukung partisipasi selama perayaan liturgi (memungkinkan adanya perarakan komuni). Selain itu jarak antar bangku dan bentuk bangku disesuaikan dengan kebutuhan gerak-gerik simbolis selama perayaan liturgi.

\section{Penerapan Teori Panoptisisme untuk Menganalisis Peraturan \\ Pembangunan Gereja Katolik}

Gereja Katolik memiliki peraturanperaturan yang harus dipatuhi. Salah satunya adalah peraturan di dalam pembangunan gereja Katolik. Menurut literatur tentang peraturan pembangunan gereja Katolik, pembentukan ruang pada liturgi di dalam gereja Katolik sebaiknya mengikuti tiga prinsip, yaitu prinsip kesatuan, prinsip fungsi dan prinsip simbolisme. Prinsip kesatuan berarti tata ruang liturgi harus mencerminkan kesatuan umat Allah sebagai Tubuh Kristus. Secara praktis, tata ruang liturgi harus memungkinkan terjadinya kebersamaan dan kesatuan umat. Prinsip fungsi dan peran berarti tata ruang harus memperhatikan aneka fungsi dan tindakan yang dilakukan di dalam perayaan liturgis, selain itu memungkinkan partisipasi aktif dari seluruh umat beriman. Prinsip simbolisme berarti tata ruang liturgis harus mampu membawa umat kepada realitas ilahi dan martabat agung dari apa yang dirayakan dalam liturgi (Martasudjita, 1998).

Di dalam pengupayaan terciptanya ketiga prinsip ini, maka gereja Katolik memiliki peraturan yang digunakan di dalam perancangan dan pembangunan setiap gereja Katolik di seluruh dunia. Beberapa peraturan ini antara lain: (1) Letak ruang gereja hendaknya memperhitungkan ciri khas gereja yang menuntut keanggunan, ketenangan, kesucian dan keluhuran. (prinsip kesatuan) (2) Ruangan dalam gereja harus menunjukkan susunan hirarkis umat dan keanekaragaman tugas-tugas melalui penataannya (prinsip fungsi dan simbolisme) (3) Jarak tempat duduk, ruas jalan untuk komuni, ukuran dan bentuk tempat duduk, jarak umat dari imam antara satu sama lain harus diperhitungkan untuk kelancaran upacara liturgi dan kenyamanan umat ketika mengikuti misa (prinsip fungsi dan simbolisme) (4) Altar adalah pusat perayaan liturgi dan merupakan poros komunitas yang melaksanakan perayaan, hendaknya jelas terlihat dari segala pihak. (prinsip kesatuan, fungsi dan simbolisme) (5) Mimbar merupakan tempat khusus untuk pewartaan Sabda Tuhan (prinsip kesatuan, fungsi dan simbolisme). (6) Tempat duduk pemimpin harus menandakan sebagai tempat seorang pemimpin, dan bisa berkomunikasi langsung dengan umat, meskipun tempatnya berada di panti imam (prinsip kesatuan, fungsi dan simbolisme) (7) Tabernakel diletakkan di suatu yang khusus, tidak dapat dipindahkan, kuat, tertutup dan tidak 
dapat dilintasi umat, mudah terlihat dari siapapun yang memasuki gereja dan disertai dengan lampu khusus yang selalu menyala sebagai tanda kehadiran Kristus (prinsip simbolisme) (8) Tempat duduk umat mendukung partisipasi umat selama perayaan liturgi melalui jarak antar bangku dan bentuk bangku disesuaikan dengan kebutuhan gerak-gerik simbolis (prinsip fungsi).

Selain peraturan mengenai tabernakel dan altar di dalam PUMR, Ada pula peraturan di dalam Konsili Vatikan II mengenai letak tabernakel dan altar berdasarkan variasi bentuk Misa. Gereja Katolik mengakui dua variasi bentuk perayaan misa, yaitu: Misa Tridentina/Latin Tradisional (Misa sebelum Konsili Vatikan II) dengan Misa Novus Ordo (Misa setelah Konsili Vatikan II tahun 1962 dan banyak diterapkan di Indonesia). Adapun perbedaan diantara keduanya (yang terkait langsung dengan penataan ruang dan mempengaruhi partisipasi umat dan imam di dalam Misa) adalah pada posisi tabernakel dan altar. Di dalam Misa Tridentina, selama mempersembahkan Misa Kudus, posisi imam mengarah kepada arah timur atau membelakangi umat. Imam merupakan perwakilan yang secara khusus ditunjuk oleh Kristus sendiri dengan tahbisan imamat suci-Nya untuk mempersembahkan Misa Kudus serta menjadi bagian dari umat sendiri. Ini berarti imam merupakan perwakilan yang diangkat oleh umat sendiri untuk menjadi perwakilan mereka untuk menghadap Kristus dan sang Imam mengajak seluruh umat untuk mengarahkan perhatiannya kepada Tuhan.

Sementara itu, pada Misa Novus Ordo, posisi imam menghadap ke arah barat atau menghadap kepada umat. Imam tetap mempersembahkan Misa Kudus dengan menghadap salib kecil yang posisinya diletakkan di atas altar di bagian tengah depan. Selain itu, posisi Imam yang menghadap umat memiliki makna bahwa Imam adalah pemimpin umat untuk menghadap Tuhan dan mempersembahkan Misa Kudus kepada-Nya. Pergeseran kedudukan ini, walaupun kecil namun sangat berpengaruh dalam setiap perayaan Misa Kudus. Perhatian umat bukan lagi mengarah kepada Allah tetapi mulai bergeser kepada Imam sebagai sentral dari Misa Kudus.

Peraturan yang dituliskan disini sesuai dengan batasan pembahasan penelitian yang difokuskan pada ruang dalam pada gereja Katolik yang digunakan untuk aktivitas beribadah, meliputi area tabernakel, panti imam, area panti umat dan area transisi. Sub-bab berikutnya akan membahas mengenaibagaimana letak keterkaitan prinsip-prinsip panoptisisme-arsitektur kontrol dengan peraturan perancangan gereja Katolik (untuk melihat ada tidaknya panoptisisme di dalam peraturan perancangan gereja Katolik) dengan menggunakan metode kritik normatif.

Berikut tabel analisis Teknik Panoptisisme - Pola Rancang Arsitektur Kontrol dengan Peraturan Pembangunan Gereja Katolik (Tabel 2). 
Tabel 2. Tabel AnalisisTeknik Panoptisisme -Pola Rancang Arsitektur Kontrol dengan Peraturan Pembangunan Gereja Katolik.

\begin{tabular}{|c|c|c|c|}
\hline No & $\begin{array}{l}\text { Teori } \\
\text { Panoptisisme }\end{array}$ & $\begin{array}{l}\text { Teori Arsitektur } \\
\text { Kontrol }\end{array}$ & Peraturan Gerja Katolik \\
\hline \multirow[t]{3}{*}{1} & \multirow[t]{3}{*}{$\begin{array}{l}\text { Penyekat } \\
\text { (Penyekatan di } \\
\text { dalam panoptisisme } \\
\text { melalui penyekatan } \\
\text { yang jelas dan } \\
\text { pengelolaan bukaan } \\
\text { yang jelas, } \\
\text { bertujuan untuk } \\
\text { kontrol aktivitas } \\
\text { pengguna dan } \\
\text { memudahkan } \\
\text { pengawasan) }\end{array}$} & $\begin{array}{l}\text { Pola penataan } \\
\text { fisik elemen } \\
\text { bangunan }\end{array}$ & $\begin{array}{l}\text { 1. Positioning sekat berupa dinding yang } \\
\text { terletak pada bagian depan gereja } \\
\text { 2. Positioning sekat berupa penataan tempat } \\
\text { duduk umat, yang dirancang sedemikian rupa } \\
\text { untuk mengakomodasi gerakan umat. } \\
\text { 3. Positioning sekat berupa tangga (minimal } \\
1 \text { tangga) yang membatasi area panti umat } \\
\text { dengan panti imam } \\
\text { 4. Positioning sekat pada area Tabernakel } \\
\text { yang berupa perabot tertutup dan ada tangga. }\end{array}$ \\
\hline & & Pola material & $\begin{array}{l}\text { Pada pola material pada penyekat yang } \\
\text { digunakan dapat mempengaruhi tingkat } \\
\text { batasan visual pengguna. Pola material } \\
\text { disesuaikan dengan positioning sekat. }\end{array}$ \\
\hline & & Pola pengawasan & $\begin{array}{l}\text { Sekat pada pola pengawasan melalui } \\
\text { perancangan layout dapat membantu } \\
\text { klasifikasi ruang ( } 5 \text { tipe ruang yaitu stealthy } \\
\text { space; slippery space; crusty space; prickly } \\
\text { space dan jittery space) untuk memudahkan } \\
\text { pengawasan dan pengontrolan pengguna di } \\
\text { dalam panoptisisme. }\end{array}$ \\
\hline \multirow[t]{3}{*}{2} & \multirow[t]{3}{*}{$\begin{array}{l}\text { Pengelompokan } \\
\text { (pengelompokan di } \\
\text { dalam panoptisisme } \\
\text { bertujuan untuk } \\
\text { memudahkan } \\
\text { pengontrolan dan } \\
\text { pengawasan } \\
\text { melalui } \\
\text { karakterisasi dan } \\
\text { klasifikasi) }\end{array}$} & $\begin{array}{l}\text { Pola penataan } \\
\text { fisik elemen } \\
\text { bangunan }\end{array}$ & $\begin{array}{l}\text { Pada pola pengelompokan yang pertama, } \\
\text { yaitu pada pola penataan fisik elemen } \\
\text { bangunan aspek positioning dan } \\
\text { pengelompokan dalam layout terlihat dari } \\
\text { penataan layout tipikal gereja Katolik. Pola } \\
\text { pengelompokan ini dapat terjadi pada ruang } \\
\text { atau perabot yang diorganisasi. Pada gereja } \\
\text { Katolik, dimana ruang-ruang yang terjadi } \\
\text { diatur oleh sumbu dengan orientasi menuju } \\
\text { kepada area panti imam (Panti imam } \\
\text { merupakan pusat dari pelayanan liturgi) } \\
\text { sehingga ruang-ruang pada Gereja Katolik } \\
\text { dikelompokkan berdasarkan sumbu } \\
\text { mengarah ke area panti imam. } \\
\text { Penataan perabot pada Gereja Katolik juga } \\
\text { dikelompokkan dan diatur berdasarkan } \\
\text { bentuk yang sama dan / atau bentuk dasar } \\
\text { yang sama }\end{array}$ \\
\hline & & Pola material & $\begin{array}{l}\text { Pada pola kedua yaitu pola material } \\
\text { (termasuk di dalamnya material, tekstur, } \\
\text { warna), pengelompokan bisa juga } \\
\text { diaplikasikan pada pola material terutama } \\
\text { pola material dan warna, dimana material- } \\
\text { material dan warna-warna yang sama } \\
\text { diaplikasikan pada ruang umat dengan warna } \\
\text { yang sama. }\end{array}$ \\
\hline & & Pola pengawasan & $\begin{array}{l}\text { Pengelompokan pada pola pengawasan } \\
\text { melalui perancangan layout dapat membantu } \\
\text { klasifikasi ruang yang diperlukan di dalam } \\
\text { panoptisisme (melalui lima tipe ruang yaitu } \\
\text { stealthy space; slippery space; crusty space; } \\
\text { prickly space dan jittery space) dan teknologi }\end{array}$ \\
\hline
\end{tabular}




\begin{tabular}{|c|c|c|c|c|}
\hline No & $\begin{array}{l}\text { Teori } \\
\text { Panoptisisme }\end{array}$ & $\begin{array}{l}\text { Teori Arsitektur } \\
\text { Kontrol }\end{array}$ & & Peraturan Gerja Katolik \\
\hline & & & & $\begin{array}{l}\text { CCTV untuk memudahkan pengawasan dan } \\
\text { pengontrolan pengguna di dalam } \\
\text { panoptisisme }\end{array}$ \\
\hline \multirow[t]{3}{*}{3} & \multirow{3}{*}{$\begin{array}{l}\text { Kontrol Aktivitas } \\
\text { pengontrolan } \\
\text { aktivitas di dalam } \\
\text { panoptisisme, } \\
\text { variabel kultur, } \\
\text { religi dan perilaku- } \\
\text { lah yang sangat } \\
\text { beperan terutama } \\
\text { dalam hal } \\
\text { membantu } \\
\text { terciptanya disiplin } \\
\text { kuasa pada } \\
\text { masyarakat) }\end{array}$} & $\begin{array}{l}\text { Pola penataan } \\
\text { fisik elemen } \\
\text { bangunan }\end{array}$ & $\mathbf{\square}$ & $\begin{array}{l}\text { Positioning kontrol yang pertama pada umat } \\
\text { sebagai pengguna area panti umat, melalui } \\
\text { kontrol perabot dan penataannya. Kontrol } \\
\text { aktivitas yang kedua pada pelaksana tugas } \\
\text { jemaat (seperti misdinar, lektor, koor dan } \\
\text { juga petugas kolekte) dikontrol melalui } \\
\text { perabot yang digunakan untuk memudahkan } \\
\text { partisipasi mereka di dalam liturgi. }\end{array}$ \\
\hline & & Pola material & $\square$ & $\begin{array}{l}\text { Pada pola kedua yaitu pola material } \\
\text { (termasuk di dalamnya material, tekstur, } \\
\text { warna),aktivitas pengguna bisa dibatasi } \\
\text { melalui penggunaan material yang sesuai } \\
\text { dengan aktivitas pengguna. Namun terkait } \\
\text { peraturan pembangunan gereja Katolik, tidak } \\
\text { ada peraturan khusus mengenai ini, }\end{array}$ \\
\hline & & Pola pengawasan & $\mathbf{\square}$ & $\begin{array}{l}\text { Aktivitas pengguna dapat dikontrol melalui } \\
\text { pola pengawasan melalui perancangan layout } \\
\text { utamanya melalui teknologi. Klasifikasi } \\
\text { ruang di dalam pola perancangan ( } 5 \text { tipe } \\
\text { ruang yaitu stealthy space; slippery space; } \\
\text { crusty space; prickly space dan jittery space) } \\
\text { untuk memudahkan pengawasan dan } \\
\text { pengontrolan aktivitas pengguna di dalam } \\
\text { gereja Katolik. }\end{array}$ \\
\hline \multirow[t]{3}{*}{4} & \multirow{3}{*}{$\begin{array}{l}\text { Berorientasi } \\
\text { memusat (orientasi } \\
\text { pada pusat di dalam } \\
\text { panoptisisme } \\
\text { dengan tujuan agar } \\
\text { orientasi yang } \\
\text { diawasi hanya pada } \\
\text { satu titik) }\end{array}$} & $\begin{array}{l}\text { Pola penataan } \\
\text { fisik elemen } \\
\text { bangunan }\end{array}$ & - & $\begin{array}{l}\text { Pada pola yang pertama, yaitu pola penataan } \\
\text { fisik elemen bangunan, orientasi pusat dapat } \\
\text { dilihat dari aspek positioning aktivitas di } \\
\text { dalam Gereja Katolik. Para umat dibuat } \\
\text { memandang pusat dari semuanya (mulai dari } \\
\text { aktivitas sampai ke bentuk ruangan, penataan } \\
\text { perabot dan sirkulasi diarahkan memusat } \\
\text { kepada satu titik) yaitu pada area panti umat } \\
\text { utamanya pada altar }\end{array}$ \\
\hline & & Pola material & $\square$ & $\begin{array}{l}\text { Pada peraturan pembangunan gereja Katolik, } \\
\text { tidak ada peraturan khusus mengenai pola } \\
\text { material untuk orientasi pusat namun bukan } \\
\text { berarti tidak ada pengaplikasikannya pada } \\
\text { bangunan gereja Katolik. Warna pada area } \\
\text { panti imam lebih terang dibandingkan } \\
\text { dengan area panti umat, akan membuat umat } \\
\text { berorientasi ke panti imam. }\end{array}$ \\
\hline & & Pola pengawasan & - & $\begin{array}{l}\text { Orientasi kepada pusat juga dapat dikontrol } \\
\text { melalui pola pengawasan melalui } \\
\text { perancangan layout dan teknologi. Teknologi } \\
\text { seperti CCTV juga dimanfaatkan untuk } \\
\text { memudahkan kontrol orientasi terpusat. } \\
\text { Pemanfaatan teknologi CCTV di dalam } \\
\text { gereja Katolik, memudahkan umat untuk } \\
\text { berorientasi kepada area panti imam. }\end{array}$ \\
\hline
\end{tabular}




\begin{tabular}{|c|c|c|c|c|}
\hline No & $\begin{array}{l}\text { Teori } \\
\text { Panoptisisme }\end{array}$ & $\begin{array}{l}\text { Teori Arsitektur } \\
\text { Kontrol }\end{array}$ & & Peraturan Gerja Katolik \\
\hline \multirow[t]{3}{*}{5} & \multirow[t]{3}{*}{$\begin{array}{l}\text { Hirarki (hirarki } \\
\text { memiliki peranan } \\
\text { untuk mengawasi } \\
\text { bawahannya supaya } \\
\text { mereka lebih } \\
\text { terkontrol) }\end{array}$} & $\begin{array}{l}\text { Pola penataan } \\
\text { fisik elemen } \\
\text { bangunan }\end{array}$ & - & $\begin{array}{l}\text { Pada pola yang pertama, yaitu pola penataan } \\
\text { fisik elemen bangunan, hirarki dapat dilihat } \\
\text { dari aspek positioning / penempatan } \\
\text { berdasarkan susunan organis hirarkis di } \\
\text { dalam Gereja Katolik. Bentuk perabot juga } \\
\text { dapat menunjukkan hirarki. Bentuk perabot } \\
\text { seorang pimpinan berbeda dengan umat. } \\
\text { Hirarki juga bisa dilihat dari tingkat privasi } \\
\text { sebuah ruangan. Ruang yang memiliki } \\
\text { keprivasian tinggi biasanya tertutup dan } \\
\text { tidak terbuka untuk umum. }\end{array}$ \\
\hline & & Pola material & $\square$ & $\begin{array}{l}\text { Pada peraturan Gereja Katolik juga tidak } \\
\text { dituliskan mengenai hirarki berdasarkan pola } \\
\text { material. Namun, bisa saja pada penggunaan } \\
\text { warna dan material yang kontras di dalam } \\
\text { Gereja Katolik (dimana perbedaan warna dan } \\
\text { material akan membantu penciptaan suasana } \\
\text { ruang yang memiliki hirarki) sesuai yang } \\
\text { dituliskan di di dalam teknik panoptisisme } \\
\text { hirarki. }\end{array}$ \\
\hline & & Pola pengawasan & - & $\begin{array}{l}\text { Pola pengawasan pada hirarki di dalam } \\
\text { peraturan perencanaan pembangunan Gereja } \\
\text { Katolik, dimana ruang crusty space (ruang } \\
\text { yang tidak dapat diakses karena adanya } \\
\text { penghalang) berupa tangga (minimal } 1 \\
\text { tangga) yang membatasi area panti umat } \\
\text { dengan panti imam (tempat imam dan hanya } \\
\text { boleh untuk petugas liturgi yang } \\
\text { berkepentingan yang boleh masuk dan } \\
\text { slippery space (ruang yang terlihat namun } \\
\text { tidak untuk didekati) untuk area tabernakel } \\
\text { bentuk tabernakel ini mudah terlihat dari } \\
\text { siapapun yang memasuki gereja (namun } \\
\text { tidak bisa melihat isinya) dan hanya imam } \\
\text { yang bisa melintasi area ini }\end{array}$ \\
\hline \multirow[t]{3}{*}{6} & \multirow{3}{*}{$\begin{array}{l}\text { Sistem Pengawasan } \\
\text { Interior (sistem } \\
\text { pengawasan di } \\
\text { dalam panoptisisme } \\
\text { dapat bekerja } \\
\text { secara optimal } \\
\text { maka diperlukan } \\
\text { sistem pengawasan } \\
\text { interior dengan } \\
\text { teknologi terkini.) }\end{array}$} & $\begin{array}{l}\text { Pola penataan } \\
\text { fisik elemen } \\
\text { bangunan }\end{array}$ & - & \\
\hline & & Pola material & - & \\
\hline & & Pola pengawasan & घ & $\begin{array}{l}\text { Pola pengawasan untuk sistem pengawasan } \\
\text { pada perencanaan Gereja Katolik } \\
\text { teraplikasikan lewat perancangan jittery } \\
\text { space (ruang yang terus menerus di bawah } \\
\text { pengawasan) pada area panti umat, dimana } \\
\text { ruang umat ini secara terus menerus diawasi } \\
\text { demi kenyamanan umat (dengan pengawasan } \\
\text { ini diharapkan pengguna / umat berperilaku } \\
\text { sesuai yang diharapkan) dan penggunaan } \\
\text { teknologi (teknologi untuk CCTV dan } \\
\text { pengeras suara) sesuai dengan kebutuhan } \\
\text { panoptisisme pengawasan. }\end{array}$ \\
\hline
\end{tabular}

Keterangan: - = Ada panoptisisme dan tertulis di dalam Peraturan Pembangunan Gereja Katolik

$\square=$ Bisa ada / tidak ada Panoptisisme,karena Tidak Tertulis di dalam Peraturan Pembangunan Gereja Katolik.

- = Tidak Ada panoptisisme dan tidak tertulis di dalam Peraturan Pembangunan Gereja Katolik

Sumber: Hasil Analisis, 2016 


\section{Kesimpulan}

Dari hasil analisis di atas dapat disimpulkan bahwa:panoptisisme yang diungkapkan oleh Michel Foucault merupakan bagian dari arsitektur kontrol. Foucault menangkap esensi pengawasan dua arah, dari desain panoptikon Jeremy Bentham (yang kemudian disebut sebagai panoptisisme). Esensinya adalah bagaimana menerapkan disiplin kuasa dan pengawasan kepada sekelompok masyarakat secara otomatis, melalui desain arsitektur yang sesuai dengan panoptikon. Panoptisisme merupakan teknik dan mekanisme disiplin kuasa. Mekanisme ini didefinisikan dengan teknik panoptisisme melalui penataan ruang, aktifitas dan perilaku. Ada 6 macam teknik panoptisisme yang bisa dikembangkan di dalam arsitektur untuk pengontrolan dan pengawasan pengguna, yaitu teknik penyekatan, pengelompokan, kontrol aktivitas, orientasi terpusat, hirarki dan sistem pengawasan. Aktivitas dan perilaku pengguna diawasi, dikontrol melalui tatanan arsitektur panoptikon dan ruangannya sehingga pengguna tidak melakukan hal yang tidak sesuai yang direncanakan.

Arsitektur kontrol ini berfungsi sebagai mekanisme pola rancang arsitektur dari teknik panoptisisme dimana ada tiga pola (penataan fisik elemen bangunan, material dan pengawasan) yang dapat digunakan untuk melihat kuasa disiplin di dalam sebuah desain. Teori arsitektur kontrol merupakan elemen pelengkap (yang berupa pola rancang) dari teknik dan aturan panoptisisme.

Panoptisisme dan arsitektur kontrol ini saling melengkapi. Penggabungan panoptisisme dan arsitektur kontrol ini akan membantu memahami ruangruang yang berstruktur dan menonjolkan konsep kuasa, seperti ruang penjara, rumah sakit, gereja, sekolah, dan pabrik.

Ruang kuasa dan struktur panoptisisme di dalam gereja Katolik, ditonjolkan melalui hubungan imam/tabernakel dan salib Tuhan sebagai pengawas dan umat sebagai yang diawasi. Adanya pengawasan panoptisisme di dalam ruang gereja Katolik ini, membuat umat berperilaku sesuai yang diharapkan (seperti sikap hening saat memasuki ruang gereja). Bangunan gereja Katolik memang dirancang sedemikian rupa melalui peraturan yang diciptakannya, sehingga tercipta sistem panoptisisme dan arsitektur kontrol terhadap pengguna ruang. Di sini, gereja Katolik secara tidak langsung menonjolkan konsep struktur dan kekuasaannya di dalam setiap bangunan arsitekturnya. Panoptisisme hadir pada bangunan gereja Katolik, baik yang dibangun sebelum Konsili Vatikan II dan sesudah Konsili Vatikan II

\section{Ucapan Terima Kasih}

Peneliti mengucapkan terimakasih kepada program studi Desain Interior, Universitas Kristen Petra Surabaya atas dukungannya.

\section{Daftar Pustaka}

Fontana-Giusti, G. (2013). Foucault for architects. London: Routledge.

Foucault, M. (1977). Discipline and punishment: The birth of the prison. London: Billing \& Sons.

Groat, L. (2002). Qualitative research. in L. Groat, \& D. Wang, Architectural research methods (pp. 173-202). New York: John Wiley \& Sons, Inc. 
Katyal, N. K. (2002). Architecture as crime control. Yale Law Journal Vol 111.

Leach, N. (1997). Rethinking architecture: A cultural reader theory. London: Routledge.

Martasudjita, E. (1998). Memahami simbol-simbol dalam liturgi: Dasar teologi liturgis, makna simbol, pakaian, warna, ruang, tahun dan musik liturgi. Yogyakarta: Penerbit Kanisius.

Neufert, E. (1997). Data arsitek jilid 1 edisi 33. Jakarta: PT. Erlangga.

Pedoman Umum Misale Romawi (PUMR). (1969). Jakarta: Penerbit Nusa Indah.

Windhu, I. M. (1997). Mengenal ruangan dan perlengkapan dan petugas liturgi. Yogyakarta: Penerbit Kanisius. 